\title{
Perancangan Sarana Mobilitas Hijau Berbasis Teknologi Tepat Guna Sebagai Ikon Ecotourism Di Desa Suroteleng, Selo, Boyolali
}

\author{
Syawaluddin Adha Pohan ${ }^{\mathrm{a}, 1}$, Arif Kusumawanto ${ }^{\mathrm{b}, 2}$, Alva Edy Tontowi ${ }^{\mathrm{c}, 3}$ \\ ${ }^{a}$ Magister Teknik Sistem, Fakultas Teknik Universitas Gadjah Mada, Yogyakarta \\ ${ }^{\mathrm{b}}$ Departemen Teknik Arsitektur dan Perencanaan Universitas Gadjah Mada, Yogyakarta \\ 'Departemen Teknik Mesin dan Industri Universitas Gadjah Mada, Yogyakarta \\ 'adha.pohan@mail.ugm.ac.id; ${ }^{2}$ arifk@ugm.ac.id; ${ }^{3}$ alvaedytontowi@ugm.ac.id
}

ARTICLE INFO

Keywords

Suroteleng, ecotourism, downhill, green mobility.

\begin{abstract}
Suroteleng Village (Selo Subdistrict, Boyolali Regency, Central Java) is located between the slopes of Mount Merapi to the north and the slopes of Mount Merbabu to the south. This makes Suroteleng Village potentially as a strategic ecotourism destination. Nevertheless, the local government wants to have a distinctive tourism identity, and downhill biking (cycling from the top of the mountain slope to the lower point) is proposed to be an iconic nature tourism activity in the village. Therefore it is necessary to design mobility facilities, which can facilitate tourists to easily be able to get to the starting point of cycling, which is located on the upper slopes of the mountain. The mobility facility was designed based on two aspects, namely: 1) System design theory (system engineering), and 2) Global Sustainable Tourism Council Destination Criteria; so that it meets the requirements as a green mobility based on appropriate technologies and become icon in the ecotourism area of Suroteleng Village.
\end{abstract}

\section{Pendahuluan}

Pariwisata secara global telah mendapat pengakuan sebagai salah satu sektor unggulan, yang menjadi salah satu sektor kunci menuju peningkatan kesejahteraan masyarakat dan pembangunan wilayah di suatu negara. Dalam Rencana Strategis Pengembangan Destinasi dan Industri Pariwisata tahun 2015 - 2019 yang diterbitkan oleh Kementerian Pariwisata Republik Indonesia, disebutkan bahwa menurut data dari organisasi pariwisata dunia, yakni United Nation World Tourism Organization (UNWTO), sektor pariwisata berkontribusi sebesar 9\% terhadap GDP dunia. GDP (Gross Domestic Product), atau di Indonesia disebut produk domestik bruto yang disingkat PDB, merupakan salah satu aspek dalam perhitungan pendapatan suatu daerah, sekaligus menjadi salah satu indikator pertumbuhan ekonomi suatu daerah. Kontribusi sebesar 9\% terhadap GDP dunia tersebut, setara dengan 1 dari 11 lapangan kerja secara global dibuka oleh sektor pariwisata. Secara nasional, sektor pariwisata berkontribusi sebesar 4\% terhadap PDB pada periode 2010 - 2014 . Kontribusi tersebut setara dengan 10,13 juta tenaga kerja diserap oleh sektor pariwisata, dengan nilai devisa 10 milyar USD. Hal tersebut membuat sektor pariwisata selalu berada di jajaran 5 besar dalam daftar komoditas penghasil devisa negara pada tahun 2011-2015 (Deputi Bidang Pengembangan Destinasi dan Industri Pariwisata, 2015).

Perkembangan pesat sektor pariwisata tersebut membuat pemerintah Indonesia memberikan mandat kepada destinasi dan industri pariwisata nasional untuk mengembangkan kepariwisataan yang berkelas dunia, memiliki daya saing, dan berkesinambungan, serta mampu mendorong pembangunan daerah, dengan tujuan utama untuk meningkatkan kontribusi ekonomi kepariwisataan Indonesia, melalui Peraturan Menteri Pariwisata No. 29 Tahun 2015. Atas dasar mandat tersebut, pemerintah Kabupaten Boyolali melalui Perda Kabupaten Boyolali No. 14 Tahun 2016, menetapkan bahwa strategi kepariwisataan yang berbasis hasil pertanian dan berwawasan kesinambungan lingkungan (ecotourism), menjadi dasar dalam pengembangan sektor pariwisata di Kabupaten Boyolali. Oleh sebab itu, pemerintah Desa Suroteleng yang berada di bawah kepemerintahan Kabupaten Boyolali dengan segala potensi yang dimilikinya, berupaya untuk dapat 
mengaplikasikan kepariwisataan yang berwawasan kesinambungan lingkungan dalam membangun serta meningkatkan pertumbuhan ekonomi di wilayahnya.

Lanskap Desa Suroteleng dengan tingkat kemiringan yang cukup curam karena terletak di antara lereng Gunung Merapi dan Merbabu, di satu sisi menjadi tantangan dalam upaya pembangunan berbagai sarana di desa tersebut. Namun di sisi lain, bagi para pecinta sepeda gunung hal tersebut justru menjadi daya tarik tersendiri pula. Meski belum ada publikasi resmi dari pihak manapun terkait jumlah pesepeda gunung yang sering bersepeda di Desa Suroteleng, pihak pemerintah desa merasa bahwa kehadiran para pecinta sepeda gunung di Suroteleng menjadi ide dasar dalam pengaplikasian ecotourism yang ikonik bagi desanya. Sehingga, penyediaan sarana pendukung akitivitas bersepeda gunung, dianggap menjadi upaya awal yang paling tepat untuk dapat membuat Suroteleng menjadi destinasi wisata yang berdaya saing.

Sarana pendukung aktivitas bersepeda gunung yang dimaksud, selain untuk memberi kemudahan dan kenyamanan mobilitas bagi para wisatawan, diharapkan juga dapat menjadi simbol kepariwisataan yang berwawasan kesinambungan lingkungan. Untuk dapat mengakomodasi harapan tersebut, dengan kondisi letak geografis serta segala keterbatasan sumber daya yang ada (baik finansial maupun sumber daya manusia), penerapan teknologi tepat guna kereta gantung direkomendasikan sebagai sistem penopang mobilitas hijau dengan utilitas holistis. Oleh karena itu, diperlukan perancangan desain sistem kereta gantung berbasis teknologi tepat guna di desa Suroteleng.

\section{Metode Penelitian}

Terdapat 2 aspek yang saling berkombinasi dalam perancangan desain sistem kereta gantung berbasis teknologi tepat guna di Desa Suroteleng, yakni:

a. Desain sistem,

Buku System Engineering and Analysis, Fith Edition digunakan sebagai dasar dalam mendesain sistem kereta gantung yang akan dibuat, sampai pada tahap conceptual dan preliminary design.

b. Global Sustainable Tourism Council (GSTC) Criteria for destination (GSTCouncil, 2013),

Kriteria GSTC untuk destinasi pariwisata yang berkelanjutan (berkesinambungan), yakni:

1) Mendemonstrasikan pengelolaan destinasi yang berkelanjutan,

2) Memaksimalkan keuntungan ekonomi untuk masyarakat lokal dan minimalkan dampak negatif,

3) Memaksimalkan keuntungan untuk masyarakat, pengunjung dan budaya serta meminimalkan dampak negatif,

4) Memaksimalkan manfaat untuk lingkungan dan meminimalkan dampak negatif.

Selanjutnya, desain sistem kereta gantung berbasis teknologi tepat guna dirancang menggunakan peranti lunak (software) SketchUp 2019.

\section{Hasil Dan Pembahasan}

Desain sistem yang dihasilkan disajikan pada gambar berikut: 


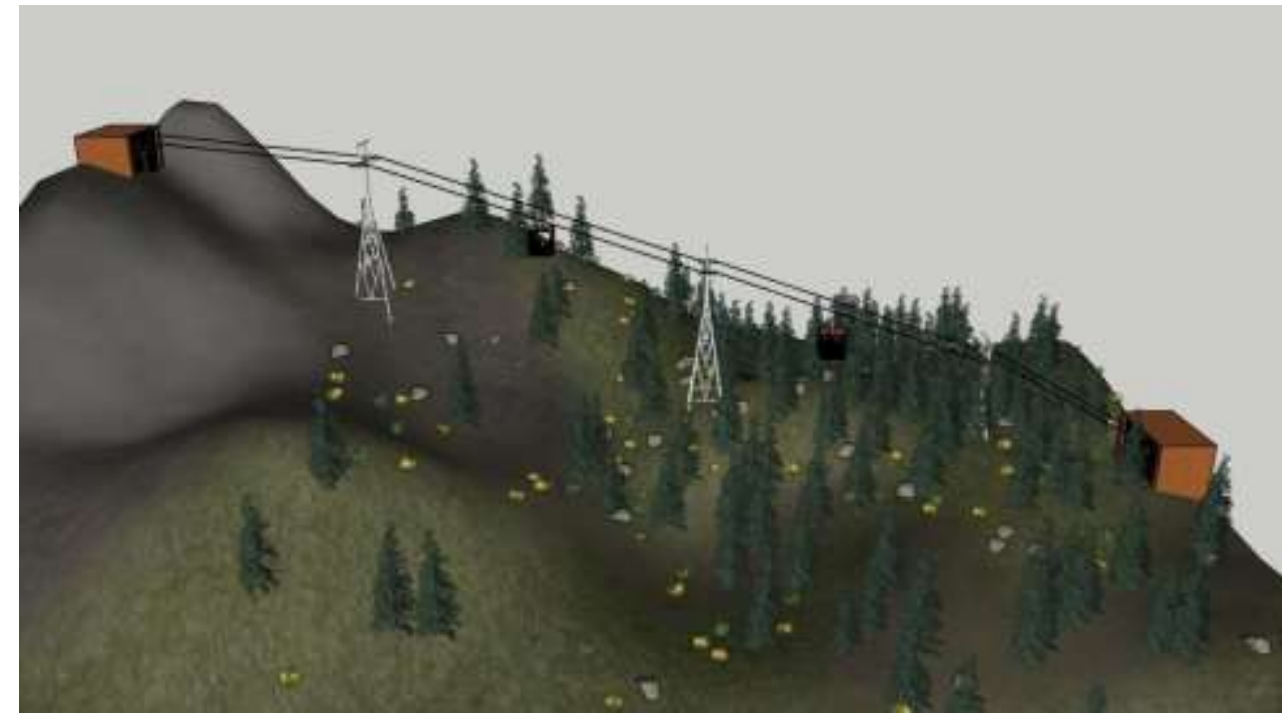

Gambar 1 Desain pendahuluan sistem yang dihasilkan

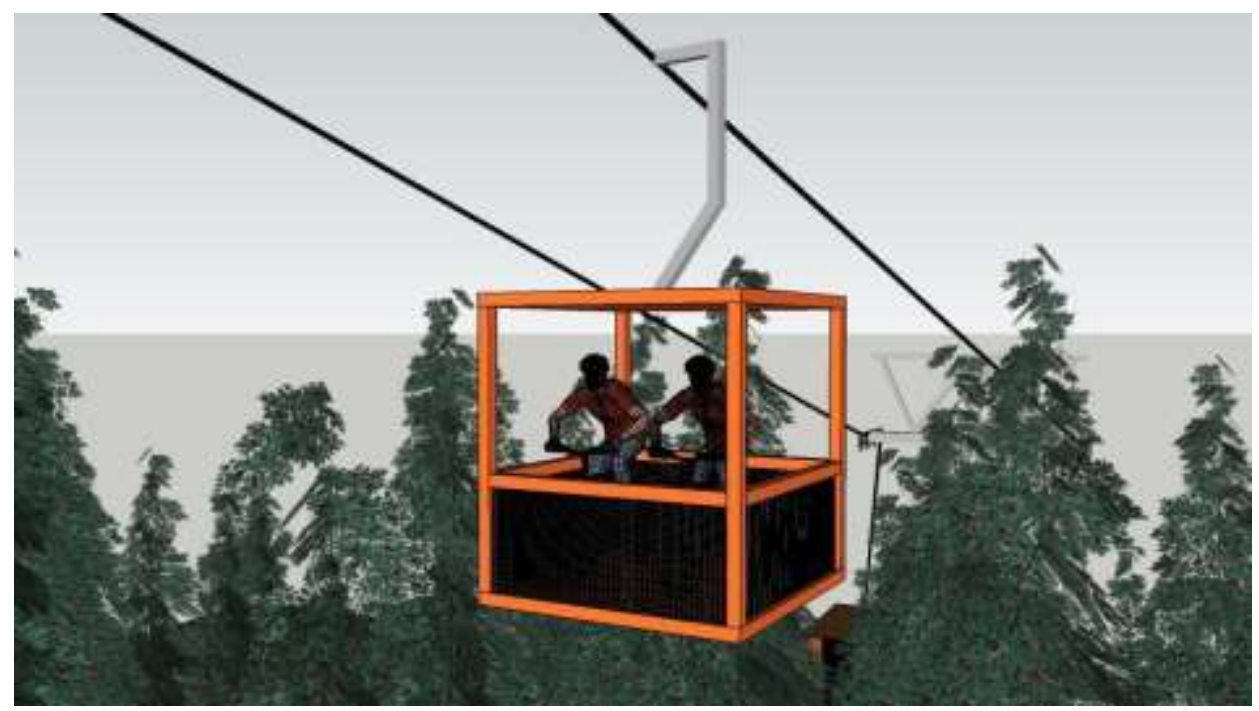

Gambar 2 Desain pendahuluan sistem yang dihasilkan

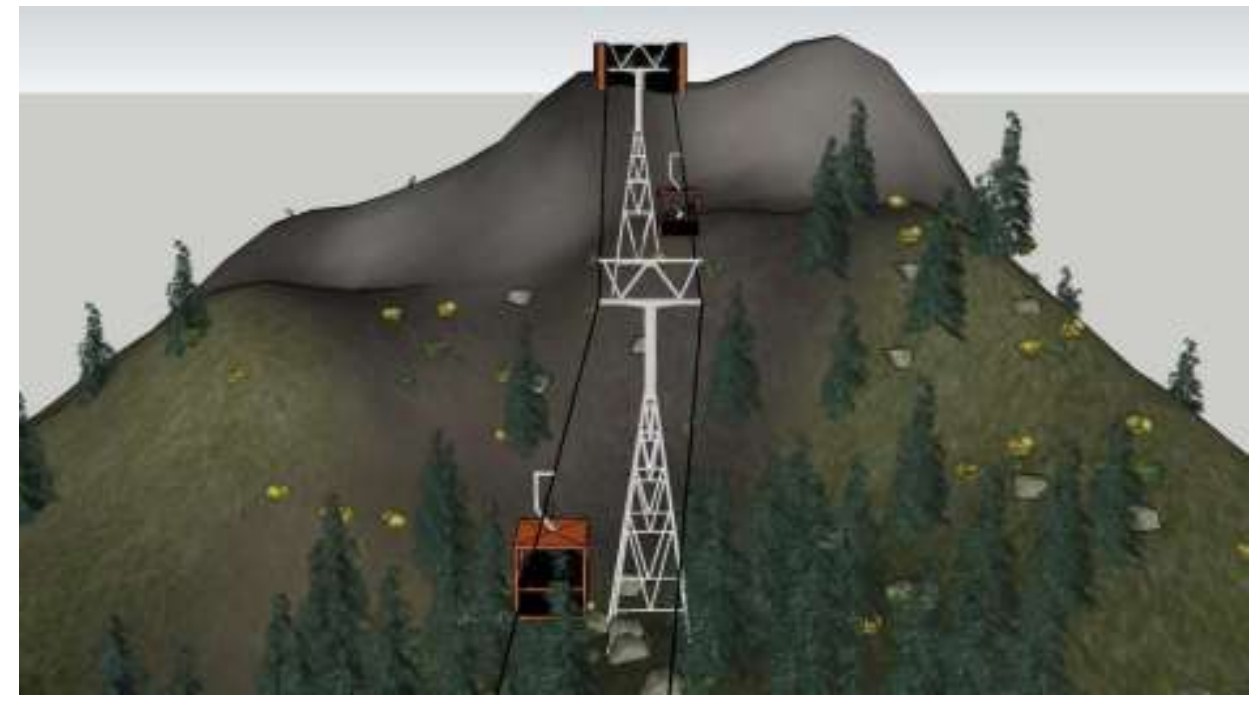

Gambar 3. Desain pendahuluan sistem yang dihasilkan 


\section{Conceptual dan preliminary design.}

Sistem secara sederhana, merupakan suatu entitas yang terdiri dari komponen-komponen yang saling berinteraksi satu sama lain dalam rangka mencapai tujuan atau fungsi dari entitias tersebut. Dalam hal ini, sistem kereta gantung yang didesain terdiri atas stasiun, kabin, tiang penyangga, serta lintasannya sebagai komponennya. Setiap komponen memiliki karakteristik serta konfigurasi sesuai fungsinya masing-masing. Berdasarkan teori system engineering (Blanchard and Fabrycky, 2014), tahap conceptual design adalah tahap paling dasar dalam menciptakan sebuah sistem. Pada tahap ini, dilakukan identifikasi kebutuhan yang akan dipenuhi oleh sistem tersebut, serta perencanaan fungsi operasional sistem yang akan dibuat. Kebutuhan yang akan dipenuhi oleh sistem yang akan dibuat ini adalah pemenuhan kebutuhan mobilitas para pesepeda gunung untuk mencapai titik awal start lintasan bersepeda gunung, di lereng gunung yang lebih tinggi dengan mudah dan aman, serta dengan biaya investasi, operasional, dan perawatan yang efisien. Perencanaan fungsi operasionalnya adalah kabin yang didesain bergerak dua arah pada masingmasing lintasannya secara bolak-balik menuju ke stasiun atas dan bawah. Atas dasar penetapan konsep sistem tersebut, selanjutnya dibuatlah gambar preliminary design (desain pendahuluan) kereta gantung (Gambar 1-3).

\section{Asesmen terhadap desain yang dibuat berdasarkan kriteria destinasi GSTC}

\section{a. Mendemonstrasikan pengelolaan destinasi yang berkelanjutan}

Desa Suroteleng pada dasarnya belum dapat sepenuhnya disebut sebagai destinasi wisata pada saat ini. Hal ini bisa sebutkan karena belum adanya aktivitas ekonomi yang benar-benar berjalan dalam rangka menawarkan atraksi atau pengalaman berwisata yang dilakukan oleh penduduk desa tersebut. Untuk itu, perancangan preliminary design system kereta gantung ini, diharapkan menjadi titik awal untuk menjadikan Suroteleng menjadi desa tujuan wisata. Desain ini jika akan nantinya diaplikasikan harus melalui tahapan proses Detail Design and Development, sampai menghasilkan design yang benar-benar siap untuk dibangun. Sebagai pengantar untuk menjadi desain yang detail, atas dasar kriteria destinasi wisata dari Global Sustainable Tourism Council, pengelolaan destinasi harus didemonstrasikan secara berkelanjutan. Oleh sebab itu, preliminary design kereta gantung yang telah dibuat ini masih membuka kemungkinan untuk berbagai jenis sumber energi baru dan terbarukan sebagai penggeraknya. Secara umum, energi yang digunakan untuk mengoperasikan kereta gantung adalah listrik, sehingga tidak menimbulkan polusi udara dan memenuhi syarat pendemonstrasian yang berkelanjutan.

\section{b. Memaksimalkan keuntungan ekonomi untuk masyarakat lokal dan minimalkan dampak negatif}

Penerapan teknologi tepat guna pada desain sistem kereta gantung yang dibuat ini bertujuan untuk mengurangi biaya investasi, operasional, serta perawatan pembangunan kereta gantung. Sejatinya sejak beberapa tahun lalu, sudah cukup banyak artikel yang dimuat oleh media berita online (seperti di antaranews.com, okezone.com, solopos.com), terkait akan dibangunnya kereta gantung berteknologi arus utama di Desa Suroteleng. Namun besarnya biaya investasi, operasional serta perawatannya menjadi salah satu tantangan utama untuk mewujudkannya. Risiko lainnya seperti riskan bencana alam serta keterbatasan kualitas sumber daya manusia, menjadi tantangan selanjutnya. Dengan menggunakan teknologi tepat guna yang berbasis pada produk lokal, dengan bantuan teknis dari akademisi dan praktisi terkait, serta pengoperasian sistem yang dapat disesuaikan dengan kualitas sumber daya manusia yang diberi pelatihan, berbagai dampak negatif dari penerapan teknologi arus utama kereta gantung dapat diminimalisir, serta dapat membuka lapangan kerja/lahan usaha baru di Suroteleng.

\section{c. Memaksimalkan keuntungan untuk masyarakat, pengunjung dan budaya serta meminimalkan dampak negatif}

Di sisi lain, tantangan yang dihadapi dalam penerapan teknologi tepat guna adalah permasalahan aspek keamanan dan aspek teknis teknologinya. Khusus pada aspek keamanan, salah satu pabrikan teknologi arus utama kereta gantung mengklaim bahwa kereta gantung merupakan alat transportasi paling aman di dunia (Doppelmayr, 2014), yang sekaligus menawarkan pengalaman berwisata yang khas bagi penggunanya. Oleh sebab itu faktor keterlibatan akademisi 
maupun praktisi terkait untuk dapat menciptakan teknologi tepat guna kereta gantung sangat krusial untuk menjamin keselamatan wisatawan. Pihak pemerintah Desa Suroteleng sendiri telah berkonsultasi dengan berbagai ahli dan tim peneliti dari beberapa instansi pendidikan tinggi seperti dari UGM dan UNS. Untuk tahap awal dari aspek teknologi, desain sistem kereta gantung berbasis teknologi tepat guna ini dapat digunakan sebagai acuan sistem dasarnya. Konfigurasi, karakteristik, serta assembling komponen-komponennya terbuka untuk para ahli dan peneliti terkait dari instansi manapun untuk dieksplorasi sehingga tetap menjamin keamanan wisatawan. Untuk aspek ekonomi, perancangan model bisnis produksi kereta gantung dalam negeri juga sudah dilakukan, dengan hasil layak secara ekonomi untuk dilaksanakan (Larutama, 2019). Artinya, pabrik kereta gantung dalam negeri secara ekonomis layak untuk didirikan. Hal ini semakin membuka lebar peluang kerja, khususnya bagi sumber daya manusia lokal. Dengan mayoritas memberdayakan sumber daya manusia lokal, diharapkan akan menjaga kearifan sosial budaya masyarakat lokal, karena tidak terlalu banyak melibatkan pihak dari luar daerah.

\section{d. Memaksimalkan manfaat untuk lingkungan dan meminimalkan dampak negatif}

Selain terbuka untuk sumber energi listrik yang tidak menimbulkan polusi udara, desain sistem yang dibuat ini juga tidak memerlukan lahan yang luas untuk pengaplikasiannya. Area sekitar lintasan kereta gantung tetap dapat dipergunakan sebagaimana biasanya, yakni sebagai lahan pertanian masyarakat. Sehingga manfaat baru sebagai sistem mobilitas bagi wisatawan, yang dapat menawarkan keuntungan ekonomi baru dapat diraih, tanpa merusak lingkungan serta sosial budaya masyarakat lokal.

\section{Kesimpulan Dan Saran}

\section{Kesimpulan}

Konsep dan desain awal kereta gantung yang dihasilkan telah memenuhi syarat sebagai destinasi pariwisata yang berkelanjutan, sesuai dengan kriteria Global Sustainable Tourism Council.

\section{Saran}

Pengembangan desain kereta gantung diperlukan untuk mempersiapkan pembangunan kereta gantung sebagai sarana mobilitas hijau di Desa Suroteleng.

\section{Daftar Pustaka}

Agregasi Solopos. (2016). Okezone.com. https://lifestyle.okezone.com/read/2016/09/02/406/1479990/wow-panjang-rel-keretagantung-di-selo-boyolali-capai-1-km.

Aries Susanto. (2016). Solopos.com. https://www.solopos.com/wisata-boyolali-panjang-rel- keretagantung-di-selo-capai-1-km-749944.

Bambang DM. (2016). Antaranews.com.

https://www.antaranews.com/berita/589019/boyolali-bangun-kereta-gantung-tingkatkankunjungan-wisatawan.

Blanchard and Fabrycky. (2014). Systems Engineering and Analysis. Pearson Education Ltd.

Edinburgh.

Deputi Bidang Pengembangan Destinasi dan Industri Pariwisata. (2015). Rencana Strategis Pengembangan Destinasi dan Industri Pariwisata tahun 2015-2019. 1-70. 
Doppelmayr. (2014). Kereta Gantung di Perkotaan.

Gstcouncil. (2013). GSTC Indikator Kinerja yang disarankan bagi Destinasi. (NOVEMBER), 110.

Larutama, W. (2019). Perancangan Model Bisnis Produksi Kereta Gantung dengan Menggunakan Business Model Canvas. Konferensi Nasional - Inovasi Lingkungan Terbangun (ILT) 2019. 24. 